\title{
Modelling the Relationship between Performance Appraisal and Organizational Productivity in Nigerian Public Sector
}

\section{Paul SO*, Olumuyiwa FO and Esther OA}

Department of Business Management, Covenant University, Ogun State, Nigeria

\begin{abstract}
Quite a number of challenges have been identified as confronting the effective and efficient practice of the performance appraisal system which includes the effect of managerial decisions, reward and its turnout in commitment and loyalty of employees which triggers productivity within the organization. Therefore, this study concentrates on 'what', 'why' and 'how' as the factors generate extreme dissatisfaction among employees and employers. Descriptive survey design method was adopted with the use of questionnaire distributed to the management and staff of some selected public sectors in Lagos State, South-West, Nigeria out of which 254 representing $85 \%$ were valid for the research. The questionnaire was structured into four sections. The study pointed that if managerial decisions are fair and just with equitable reward and promotion for job done, it will increase employees' commitment and loyalty in the organization. In the same vein, if employees were properly motivated with the necessary and adequate training needs, innovation would increase rapidly on the job and this will thereby lead to competitive positioning. In addition to this, employees agreed that if they got regular feedbacks about their performance on the jobs, it could secure competitive positioning for the organization. As this will help them to identify their strengths and weaknesses which could invariably produce opportunities to the organization they are working with and threat to their competitors.
\end{abstract}

Keywords: Reward; Motivation; Training; Feedback; Commitment; Loyalty; Innovation; Competitive positioning

\section{Introduction}

Performance appraisal has become a strategic tool for improving organizational effectiveness. Performance appraisal are often used interchangeably with performance assessment, evaluations, and performance review or employee appraisal. The significant role of performance appraisal in any establishment of organizations has become indispensable when we talk of organizational success. The success of any organization is dependent on how well the performance of every employee is effectively appraised and managed. The performance appraisal is a unique and very important aspect of career development which entails a regular review of the performance of employees in the organization [1] but doesn't stop there but goes further to communicate feedback to the employees [2,3] sees Performance appraisal as a continuous process of assessing and measuring the inputs of every employee with a view to knowing their strengths and weaknesses [4] and communicating the results back to the employees $[5,6]$ posited that Performance appraisal is an activity which include the assessment of individual or other level of performance to measure and improve performance that will help in attaining corporate objectives. Performance appraisal is a process that contributes to the effective management of individuals [1] and teams to achieve high levels of organizational performance $[7,8]$ opined that Performance appraisal is a broad concept that covers quite a number of activities that is connected to evaluate employees and improve their capability, skill, abilities through training and adequate rewards [9]. To get the best out of every employees, it becomes imperative for organizations to have a continuous activities or programmes that will help in reviewing their performance and competence and thereby communications among work groups $[10,11]$ also acclaimed that Performance management is a systematic way of communicating to employees on what they are expected to do and what the performance parameters are. Managers can only satisfy employees on a job if they give employees what they deserve for their performance so far without making an attempt to exploit employees and pay them lower than expected. Performance appraisal through a good feedback mechanism as to a lager extent help employees to know how they are progressing within the organization in carrying out their duties, tasks and responsibilities this feedback can be made available on a daily, weekly or monthly basis [12]. Quite a number of challenges have been identified as confronting the effective and efficient practice of the performance appraisal system which includes the effect of reward and its turnout in commitment and loyalty of employees which triggers productivity within the organization. From past researches [13-16] and findings, it has been observed that matching both rewards as a result of employee's performance in an organization will commit employees more to the performance appraisal process [2] and showing them that the completion of the performance targets and objectives will affect them directly [17]. Organizations fail in motivating their employees especially those that have performed excellently well over a period of time leading to a negative attitude or response from employees [9]. Motivation of employees would make them to be more innovative because they are encouraged to perform better [1]. An organization that motivates its employees makes them more innovative and creates brilliant ideas that would give the organization a competitive edge in its operating environment [8]. When employees realize that if they put in their best to the organization in carrying out their tasks and duties responsibly well, they could be promoted, have an increase in wages, better opportunities are opened to them but in situations where their performance is woeful, they attract penalties that cannot be avoided, this consciousness would push them

*Corresponding author: Paul SO, Department of Business Management, Covenant Unversity, Ogun State, Nigeria, Tel: 2348171613173; E-mail: odunayo.salau@covenantuniversity.edu.ng

Received September 01, 2014; Accepted January 03, 2015; Published January 13, 2015

Citation: Paul SO, Olumuyiwa FO, Esther OA (2015) Modelling the Relationship between Performance Appraisal and Organizational Productivity in Nigerian Public Sector. J Glob Econ 3: 129. doi:10.4172/2375-4389.1000129

Copyright: ( 2015 Paul SO, et al. This is an open-access article distributed under the terms of the Creative Commons Attribution License, which permits unrestricted use, distribution, and reproduction in any medium, provided the original author and source are credited. 
to strife towards putting in their best to avoid negative rewards and being more creative. Employees will begin to think outside the circle to generate ideas and which will lead to organizational productivity [18]. There are a number of potential benefits of organizational performance management conducting formal performance appraisals (PAs). There has been a general consensus in the belief that PAs lead to positive implications of organizations [17]. Furthermore, PAs can benefit an organization's effectiveness [16]. One way is PAs can often lead to giving individual workers feedback about their job performance [13]. From this may spawn several potential benefits such as the individual workers becoming more productive [18].

\section{Other potential benefits include:}

- Facilitation of communication: communication in organizations is considered an essential function of worker motivation [13]. It has been proposed that feedback from PAs aid in minimizing employees' perceptions of uncertainty [16]. Fundamentally, feedback and management-employee communication can serve as a guide in job performance [13].

- Enhancement of employee focus through promoting trust: behaviors, thoughts, and/or issues may distract employees from their work, and trust issues may be among these distracting factors [19]. Such factors that consume psychological energy can lower job performance and cause workers to lose sight of organizational goals [13]. Properly constructed and utilized PAs have the ability to lower distracting factors and encourage trust within the organization [20].

- Goal setting and desired performance reinforcement: organizations find it efficient to match individual worker's goals and performance with organizational goals [13]. PAs provide room for discussion in the collaboration of these individual and organizational goals [21]. Collaboration can also be advantageous by resulting in employee acceptance and satisfaction of appraisal results [22].

- Performance improvement: well constructed PAs can be valuable tools for communication with employees as pertaining to how their job performance stands with organizational expectations [16]. "At the organizational level, numerous studies have reported positive relationships between human resource management (HRM) practices" [13] and performance improvement at both the individual and organizational levels.

- Determination of training needs: "Employee training and development are crucial components in helping an organization achieve strategic initiatives" $[13,23]$. It has been argued that for PAs to truly be effective, post-appraisal opportunities for training and development in problem areas, as determined by the appraisal, must be offered [24]. PAs can especially be instrumental for identifying training needs of new employees [7]. Finally, PAs can help in the establishment and supervision of employees' career goals [16]. The overall and guiding questions of this research work is to assess the effect of performance appraisal on organizational productivity [1] viewed Performance management as a very critical approach that allows an employee to know what is expected out of him and what the performance parameters are [18]. Job satisfaction and labour productivity go hand in hand with each other and cannot be substituted for the other. Numerous studies like [17-20,24,25] affirmed that high level of labour productivity will be achieved if a worker or employee feels satisfied with his job and doesn't have any feeling of being exploited by his employees. Managers can only satisfy employees on a job if they give employees what they deserve for their performance [23] without making an attempt to exploit employees and pay them lower than expected. In spite of the attention and resources paid to the practice, it continues to generate extreme dissatisfaction among employees and employers alike and is often viewed as inaccurate, unfair, and political [24]. If the evaluation process makes the employee feel insecure or discouraged this singular feeling may scatter the whole evaluation process between the rater and rate. Feedback should be given to rates on their overall progress within the organization [25]. Such feedbacks should not be delayed but should be timely and specific. It is part of the rights of employees to know how they are progressing within the organization in carrying out their duties, tasks and responsibilities [9] and get feedback in return which should not just be on a yearly basis but also as frequent, timely as possible. Feedbacks should be provided on a continuous basis- daily, weekly or monthly reviews [12]. Feedbacks leave room for improved competitive positioning [24]. If it is done, there is the high possibility of this feedback raising an inner drive within the employee and motivating him to do more or increase his level of commitment to the organization which in turn will lead to an improved and better competitive positioning for an organization. It was observed from the study of [26] that the absence of feedback mechanism generate job dissatisfaction among employees as they see the system as ineffective and unfair. Studies on performance appraisal are no longer a new topic in the Human resource management practices and philosophies BUT in spite of the attention and resources paid to the practice, it continues to generate extreme dissatisfaction among employees and employers. Therefore, this study concentrates on 'what' the causes are, 'why' and 'how' as this causes generate extreme dissatisfaction among employees and employers. Basically, the research work aims at providing answers to the following questions which are:

1. In what ways has reward significantly influence the commitment of employees?

2. What is the influence training on employees' innovation and motivation?

3. How has promotion affected the productivity of workers in Nigerian public sectors?

4. To what extent has the role of feedback improve the organizations competitive positioning?

5. To what extent has managerial decision influenced the productivity of an employee in the public sector?

\section{Research hypotheses}

The following hypotheses were tested:

H01: Reward will not have effect on the commitment of employees.

H02: Training does not have influence on employees' innovation and motivation.

H03: Promotion does not have any significant effect on labour productivity.

H04: Giving feedback will not improve competitive advantage.

\section{Literature Review}

Also explained that one of the key determining factor of performance management and appraisal is employee engagement [26]. Contributed that the importance of employee engagement cannot be underestimated when the desire of the organization is to improve performance and productivity [9]. The effectiveness of HR systems is, in part, a task of the degree to which they are matching with both organizational and individual goals. According to [27], there are a 
great number of design features that potentially can influence the effectiveness of a performance management system, and many of these have been empirically studied to clarify their impact. Studies from $[1,9,15,17,26]$ have shown that the major and prevalent problem confronting personnel appraisal is always the mistake that the rater often commits. Some of the mistakes are halo effects (this occurs when a manager appraises the performance of an employee based on a certain characteristic), error of contrast (this occurs when the rating of an employee is dependent on the performance of another person doing similar work), central tendency error (this occurs when a rater award all employees average or above average rating), leniency or strictness error (leniency occurs when the rater rate all employee high while strictness occurs when all employees are rated low), recency effect error (this occurs when rater allows recent occurrence to influence his judgement of an individual performance) and the proximity error (this occurs when a rater uses one technique to measure different traits in individual performance).

Researches from [23,26,27] also identified that the method of personnel appraisal also go a long way in determining the success and competitive positioning of an organization [17] argued that there are many methods of appraisal that can be adopted ranging from comparing one person's performance with another, evaluating performance against set of traits to appraising the workers performance against the objectives of the organization [11]. Some of these methods as obtained in $[11,17,26]$ and are supervisory rating (where supervisor is asked to rate individual performance), person-person comparison (this is a method where people working on similar jobs are compared to determining which one is weak or strong), subordinate rating method (this is where individual employees rate their managers or supervisors), pee/group rating (is a method whereby workers in organization are grouped or peered for appraisal and percentages of performances are then given according to the performance of each group), multi-source rating (this method is based on the information collected from a cross section of the stakeholders), check list (here the rater is presented some statements which he is expected to pick the one that represents the characteristics of the employees under observation), ranking method (this method involves listing the employees according to their performance from the highest to the lowest points are therefore allocated according to the position of the individual within ranking), field review method (In this method, an expert or an officer in the HR department interview the supervisors on the performance of employees in their departments), management by objectives (this methods allow every employee in an organization to set their own objectives with which plan of achievement could be made) [9] also adduced that for every organization to achieve the corporate objectives, the methods should be properly adopted and inspite of the fact that manger and subordinates are allowed to set up their goals, they should be regularly monitored and appraised, to keep them on the organizational track. [28] pointed that the aggregate of the appraisal of the subordinates' performance are indicative of the managers' performance. The failure of any of the subordinate to meet the organizational goal is a failure of the manager [2]. Posited that the manager account for every action of the subordinate [1]

\section{Performance appraisal and related variables}

Acclaimed that through personnel research, appraisal of employees should be to discover the weakness of their employee, or why the target productivity levels is not being met and thus use the information to plan future developmental programme such as employee training, possession of better equipment or motivating their workers by providing appropriate leadership style [26].

\section{Reward}

The use of reward has been an essential factor in any company's ability to meet its goals. In every establishment of organization, especially in the public sectors, it becomes imperative to have the goal and objectives clearly stated meaning that employer has to give detailed description of each person's role [25], communicate that role to them in a concise manner and adequately reward or correct their performance [26]. If a company is just developing its appraisal system without a baseline performance to reward accordingly, there is likely to be a problem from the side of the employee which will inturn affect the goal of the organization in general. Appraisals are often developed mostly in the public sectors to reward or recognize employee(s) for a job well done. This kind of motivation for high performers also serve as a challenge for the low performers.

\section{Training}

Appraisals are done in order to identify the kind and level of employees that are low performers. Training comes in when some employees are found to be deficient in the performance of their duties [13]. This training will then serve as a means to allow such employees to acquire and obtain more and specific skills, capacities, knowledge, information and talents that will be needful in his/her subsequent task. However, both managers and employees of high performance should be continually trained as to be able to provide objective input. Several studies [20] indicated that employees are often satisfied with jobs only when it affords them the opportunity to apply their skills and abilities, freedom, as well as adequate training and seminars which creates avenues for their enhancement and self-development [21]. In Nigerian public sectors, employees are given feedback on their level of performance with a realistic period and support in improving their performance through adequate training and developmental programmes.

\section{Promotion}

It has been a culture in Nigeria public sectors that when appraisal are done, they are often linked with bonuses and not to promotion. Also, it was also observed that appraisal system in the Nigeria public sectors does not always ensure that high performer employees are treated fairly with regard to both the appraisal and resulting promotions. In developing an appraisal system for organizations, management needs to think through pay increases and promotions [29]. Numerous studies like [30] pointed that employees get motivated to work when they get frequent promotions after appraisal system in their work place. While some also argued that that factors such as promotion, training and career development, and appreciation and improved work place environment gives employees greater opportunities and this will either directly or indirectly influence their satisfaction on the job. When high performances are recorded for employees, it must be supported with a basis for pay increases and promotions. However, when developing an appraisal system, the management of the public sectors needs to consider the connection between the appraisal and pay increases or promotions. While performance feedback for development/ improvement purposes may be given verbally, a written summary of the individual's work performance must accompany a pay increase or promotion (or demotion or termination). It is crucial, therefore, that a manager or small business owner regularly document an employee's job performance. 


\section{Feedback}

An employee performance appraisal serves as a means for management to evaluate and provides feedback on employee job performance, including steps to improve on their deficiencies as needed. The study of and [27] have indicated that the feedback mechanism serves as a means of identifying their strengths and weaknesses. Some adduced that to improve the performance of an individual worker, it becomes important to first identify his area of improvement and weaknesses through feedback and assistance which assures the employee's involvement, improvement and commitment to improving his or her performance [26]. For every survival of organizational business, management needs to continually inform workers of their worth, values, strength, recognized them for a job well done and set a record of open minded and fair-minded feedback. This record of feedback in appraisal can be provided verbally but in many cases, legal experts counsel employers to maintain written records in order to provide themselves with greater legal protections. The use of 360 degree feedback can also be adopted in evaluating the performance of individual. This degree affords the manager the opportunity to assess the performance of an individual employee through his interaction with different co-workers or departments, external customers, and the employee himself. As a company increases its staff, a more formal system using a written appraisal form developed internally or externally should always be used, with the results of the appraisal being tied to salary feedback on a regular basis so that employees increases or bonuses. Whether the appraisal is provided verbally or in writing, organization needs to provide consistent can improve their work performance.

\section{Demotion, Termination, Redeployment, Transfer and Retrenchment}

A sound performance appraisal mechanism must be directed towards the achievement of every organizational goal [1]. Performance appraisal in public sectors bring uniformity in evaluation process so treat employees with the capabilities could secure the same rating. In the same vein, it provides information for controlling and carrying out important manpower planning subsystems [9] like training, demotion, pay increases, termination of employment, redeployment, retrenchment, promotion, etc. [31] asserted that this aspect could help in tackling problems emanating from instant decisions or judgment if advance information is available as a result of performance appraisal outcome. Invariably, the waywardness of an individual in the organization could be contained or removed by helping him or her through performance appraisal to adjust or shoved out. However, improving the performance of every employee and employer should be among the highest priorities of contemporary" organizations.

Performance appraisals (PAs) are conducted at least annually [24], and annual employee performance reviews appear to be the standard in most American organizations [8]. However, "it has been acknowledged that appraisals conducted more frequently (more than once a year) may have positive implications for both the organization and employee." [13]. It is suggested that regular performance feedback provided to employees may quell any unexpected and/or surprising feedback to year-end discussions [32]. In a recent research study concerning the timeliness of PAs, "one of the respondents even suggested that the performance review should be done formally and more frequently, perhaps once a month, and recorded twice a year" [14] (Figure 1).

\section{Methodology}

The study involves a survey research design and the cross sectional design which involves the observation of the sample subjects and variables as they are without making any attempt to control or manipulate them. The sampling method adopted in this paper was simple random sampling method. The sample frame for this study is 300 and out of which 254 questionnaires were valid and filled completely. The questionnaire is structured into five sections, Section (A) deals with the bio data of respondents. It is aimed at obtaining information about respondents' gender, age bracket, marital status, educational attainment and work experience. Section (B) deals with rewards and commitments, Section (C) is based on motivation and innovation, Section (D) is aimed at obtaining information as regarding effects of promotion on labour productivity and section (E) deals

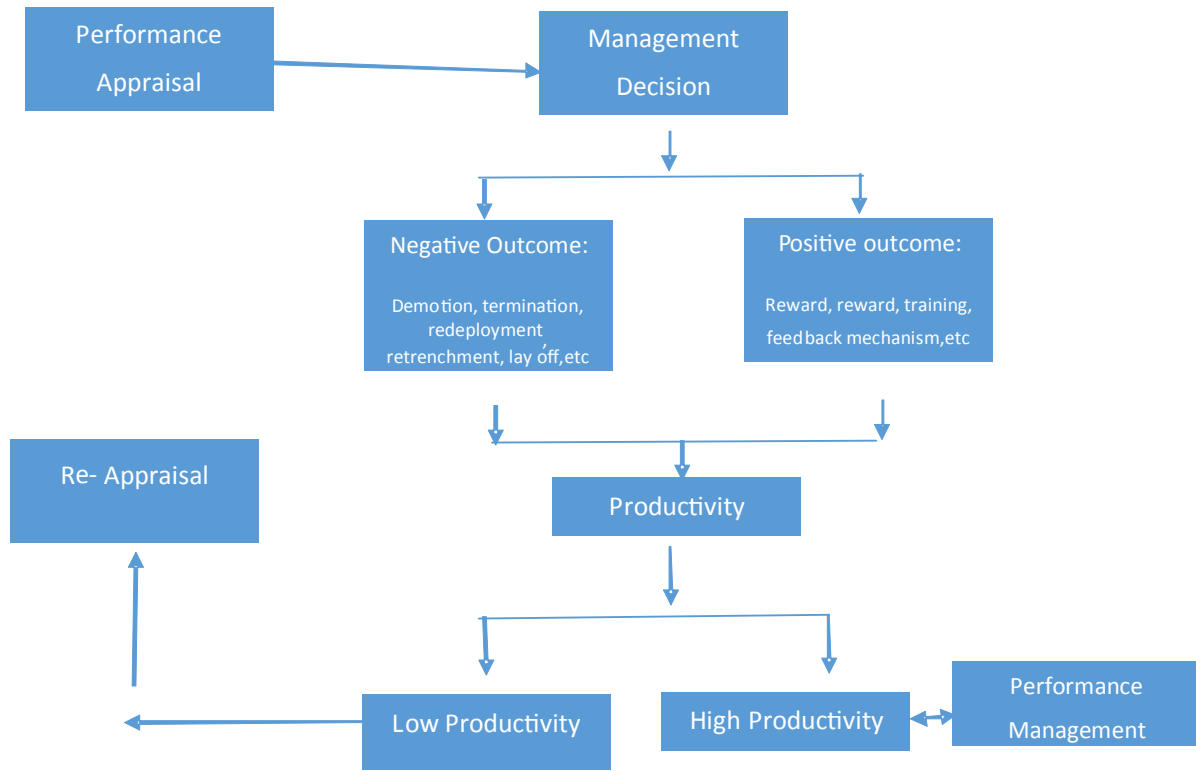

Figure 1: Proposal Research Model. 
Citation: Paul SO, Olumuyiwa FO, Esther OA (2015) Modelling the Relationship between Performance Appraisal and Organizational Productivity in Nigerian Public Sector. J Glob Econ 3: 129. doi:10.4172/2375-4389.1000129

Page 5 of 8

with competitive positioning and feedback. The questionnaires were designed in such a way to obtain data from the respondents. It was designed to gather relevant information to be used in testing hypothesis [33]. The well-structured questionnaires were in such a way that the items for which responses were needed had already been written and all that was needed was to tick the most suitable option from the list of options given, ranging from Strongly agree (SA), Agree (A), Undecided (U), Disagree (D), Strongly Disagree (SD). At the end, statistical package for social sciences (SPSS) was used to analyze the data and correlation and regression method was also used for the analysis and interpretation of the data collected.

\section{Analysis and Results}

The Table 1 shows that $148(58.3 \%)$ of the respondents are male and $106(41.7 \%)$ of the respondents are female. This therefore means that majority of the respondents are male. This table above shows that $140(55.2 \%)$ of the respondents are between the age bracket of 31-40, $58(22.8 \%)$ of the respondents are between the age bracket of 19-30, $52(20.5 \%)$ of the respondents are between the age bracket of $41-50$ and $4(1.5 \%)$ of the respondents are between the age bracket of 51 60 . This shows that majority of the respondent fall between the age brackets of 31-40. This table shows that $176(69.3 \%)$ of the respondents are married, $68(26.8 \%)$ of the respondent are single, $10(3.9 \%)$ of the respondents are others (divorced, separated, etc). This means that majority of the respondents are married. This shows that $202(79.6 \%)$ of the respondents have $0-9$ years working experience, $48(18.9 \%)$ of the respondents have 10-19 years working experience, 4 (1.5\%) of the respondents have 20-29 years working experience. This shows that majority of the respondents have 0-9 years working experience.

\section{Test of hypotheses}

H01: Managerial decisions will not have effect on the commitment and loyalty of employees (Table 2).

In the model summary table above, $\mathrm{R}^{2}$ of .153 indicates that $15.3 \%$

\begin{tabular}{|c|c|c|c|c|}
\hline \multicolumn{2}{|l|}{ Variables } & \multirow{2}{*}{$\begin{array}{c}\text { Frequency } \\
148\end{array}$} & \multirow{2}{*}{$\begin{array}{c}\text { Percent (\%) } \\
58.3\end{array}$} & \multirow{2}{*}{$\begin{array}{c}\begin{array}{c}\text { Cumulative } \\
\text { Percent }\end{array} \\
58.3\end{array}$} \\
\hline Sex & Male & & & \\
\hline & Female & 106 & 41.7 & 100.0 \\
\hline & Total & 254 & 100.0 & \\
\hline \multirow[t]{5}{*}{ Age } & $19-30$ years & 58 & 22.8 & 22.8 \\
\hline & $31-40$ years & 140 & 55.2 & 78.0 \\
\hline & $41-50$ years & 52 & 20.5 & 98.5 \\
\hline & 51 yrs and above & 04 & 1.5 & 100.0 \\
\hline & Total & 254 & 100.0 & \\
\hline \multirow[t]{4}{*}{ Marital Status } & Single & 68 & 26.8 & 26.8 \\
\hline & Married & 176 & 69.3 & 96.1 \\
\hline & Others & 10 & 3.9 & 100.0 \\
\hline & Total & 254 & 100.0 & \\
\hline \multirow[t]{4}{*}{ Length of Service } & $0-9$ years & 202 & 79.6 & 79.6 \\
\hline & 10-19 years & 48 & 18.9 & 98.5 \\
\hline & 20yrs and above & 04 & 1.5 & 100.0 \\
\hline & Total & 254 & 100.0 & \\
\hline
\end{tabular}

Table 1: Respondents Demographic Characteristics (Source: Field Survey, 2014).

\begin{tabular}{|l|c|c|c|c|}
\hline Model & R & R Square & $\begin{array}{c}\text { Adjusted R } \\
\text { Square }\end{array}$ & Std. Error of the Estimate \\
\hline 1 & $.400(a)$ & .160 & .153 & .577 \\
\hline \multicolumn{4}{|c|}{ Table 2: Model Summary. }
\end{tabular}

\begin{tabular}{|l|l|c|c|c|c|c|}
\hline Model & & $\begin{array}{c}\text { Sum of } \\
\text { Squares }\end{array}$ & Df & Mean Square & F & Sig. \\
\hline 1 & Regression & 7.903 & 1 & 7.903 & 23.742 & $.000(a)$ \\
\hline & Residual & 41.609 & 125 & .333 & & \\
\hline & Total & 49.512 & 126 & & & \\
\hline
\end{tabular}

Table 3: Anova (Researcher field survey 2014).

\begin{tabular}{|c|c|c|c|c|c|c|}
\hline \multirow[t]{2}{*}{ Model } & & \multicolumn{2}{|c|}{ Unstandardized } & \multirow{2}{*}{\begin{tabular}{|l} 
Standardized \\
Beta
\end{tabular}} & \multirow{2}{*}{$\begin{array}{l}\mathbf{t} \\
\mathrm{B}\end{array}$} & \multirow{2}{*}{$\begin{array}{l}\text { Sig. } \\
\text { Std. Error }\end{array}$} \\
\hline & & B & Std. Error & & & \\
\hline \multirow[t]{2}{*}{1} & (Constant) & 2.404 & .442 & & 5.437 & .000 \\
\hline & $\begin{array}{l}\text { Managerial decisions } \\
\text { have positive effect on } \\
\text { job commitment }\end{array}$ & .457 & .094 & .400 & 4.873 & .000 \\
\hline
\end{tabular}

Table 4: Co-efficient (Researcher field survey 2014).

\begin{tabular}{|l|c|c|c|c|}
\hline Model & $\mathbf{R}$ & $\mathbf{R}$ Square & $\begin{array}{c}\text { Adjusted R } \\
\text { Square }\end{array}$ & Std. Error of the Estimate \\
\hline 1 & $.600(a)$ & .359 & .354 & .674 \\
\hline
\end{tabular}

Table 5: Model Summary (Researcher field survey 2014).

\begin{tabular}{|l|l|c|c|c|c|c|}
\hline Model & & $\begin{array}{c}\text { Sum of } \\
\text { Squares }\end{array}$ & Df & Mean Square & F & Sig. \\
\hline 1 & Regression & 31.895 & 1 & 31.895 & 70.155 & $.000(a)$ \\
\hline & Residual & 56.829 & 125 & .455 & & \\
\hline & Total & 88.724 & 126 & & & \\
\hline
\end{tabular}

Table 6: Anova (Researcher field survey 2014).

of variation in $\mathrm{Y}$ is explained by the variation in the independent variables. This percentage is good enough in determining the goodness of fit for the model (regression equation). After taking into account the number of predictor variables in the model, adjusted $\mathrm{R}^{2}$ yielded a $57.7 \%$ variation which is moderately significant in this analysis (Table 3 ).

a. Predictors: (Constant), managerial decisions have positive effect on job commitment

b. Dependent Variable: Positive managerial decisions serve as inducements to getting commitment from employees. The ANOVA table shows the assessment of the statistical significance (sig=0.000), in which the F-value is equal to 23.742 and less than or equal to 0.05 , therefore we reject the null hypothesis (Table 4).

a. Dependent Variable: Managerial decision serves as inducements to getting commitment from employees

The table seeks to explain which of the variables is making a statistically significant unique contribution to the model looking at the sig column in the table. Based on the analysis above for which all calculated values are above the critical values, the null hypothesis $\left(\mathrm{H}_{01}\right)$ is therefore, rejected while the alternative hypothesis $\left(\mathrm{H}_{\mathrm{al}}\right)$ is accepted; managerial decision has a significant effect on the commitment of employees (Table 5).

\section{Hypothesis two}

H02: Training does not have influence on employees' motivation (Table 6).

a. Predictors: (Constant), employers ensure good training needs are provided to subordinates to motivate them to work.

b. Dependent Variable: Innovations increase in the organization when the employers motivate the employees. 
Citation: Paul SO, Olumuyiwa FO, Esther OA (2015) Modelling the Relationship between Performance Appraisal and Organizational Productivity in Nigerian Public Sector. J Glob Econ 3: 129. doi:10.4172/2375-4389.1000129

Page 6 of 8

The ANOVA table shows the assessment of the statistical significance (sig=0.000), in which the F-value is equal to70.155, and less than or equal to 0.05 , therefore we reject the null hypothesis (Table 7).

a. Dependent Variable: training and Innovations increase organizational values.

The table seeks to explain which of the variables is making a statistically significant unique contribution to the model looking at the sig column in the table. Based on the analysis above for which all calculated values are above the critical values, the null hypothesis ( $\mathrm{H} 0)$ is therefore, rejected while the alternative hypothesis (H1) is accepted; which states that training makes an employee to be innovative.

\section{Hypothesis 3}

H03: Promotion does not have any significant effect on labour productivity (Table 8 ).

In the model summary table above, $\mathrm{R}^{2}$ of .118 indicates that $11.8 \%$ of variation in $\mathrm{Y}$ is explained by the variation in the independent variables. This percentage is good enough in determining the goodness of fit for the model (regression equation). After taking into account the number of predictor variables in the model, adjusted $\mathrm{R}^{2}$ yielded a $11.1 \%$ variation which is moderately significant in this analysis (Table 9). The ANOVA table shows the assessment of the statistical significance (sig=0.000), in which the F-value is equal to 16.797, and less than or equal to 0.05 , therefore we reject the null hypothesis (Table 10).

a. Dependent Variable: If employees are promoted based on their commitment and performance, productivity will increase.The table seeks to explain which of the variables is making a statistically significant unique contribution to the model looking at the sig column

\begin{tabular}{|c|c|c|c|c|c|c|}
\hline \multirow[t]{2}{*}{ Model } & & \multicolumn{2}{|c|}{ Unstandardized } & \multirow{2}{*}{$\begin{array}{c}\text { Standardized } \\
\text { Beta }\end{array}$} & \multirow{2}{*}{$\begin{array}{l}\mathbf{t} \\
\mathrm{B}\end{array}$} & \multirow{2}{*}{\begin{tabular}{|c|} 
Sig. \\
Std. Erro
\end{tabular}} \\
\hline & & $B$ & Std. Error & & & \\
\hline \multirow[t]{2}{*}{1} & (Constant) & 1.225 & .321 & & 3.818 & .000 \\
\hline & $\begin{array}{l}\text { Innovation and motivation } \\
\text { increases through } \\
\text { adequate training } \\
\text { of employees in the } \\
\text { organization }\end{array}$ & .650 & .078 & .600 & 8.376 & .000 \\
\hline
\end{tabular}

Table 7: Coefficients (a) (Researcher field survey 2014).

\begin{tabular}{|l|c|c|c|c|}
\hline Model & $\mathbf{R}$ & $\mathbf{R}$ Square & Adjusted R Square & Std. Error of the Estimate \\
\hline 1 & $.344(\mathrm{a})$ & .118 & .111 & .751 \\
\hline
\end{tabular}

Table 8: Model Summary (Researcher field survey 2014).

\begin{tabular}{|l|l|c|c|c|c|c|}
\hline Model & & Sum of Squares & df & Mean Square & F & Sig. \\
\hline \multirow{2}{*}{1} & Regression & 9.469 & 1 & 9.469 & 16.797 & $.000(a)$ \\
\cline { 2 - 8 } & Residual & 70.468 & 125 & .564 & & \\
\cline { 2 - 7 } & Total & 79.937 & 126 & & & \\
\hline
\end{tabular}

Table 9: Anova (Researcher field survey 2014).

\begin{tabular}{|c|c|c|c|c|c|c|}
\hline \multirow[t]{2}{*}{ Model } & & \multicolumn{2}{|c|}{ Unstandardized } & \multirow{2}{*}{\begin{tabular}{|c|} 
Standardized \\
Beta \\
\end{tabular}} & \multirow{2}{*}{$\begin{array}{l}\mathbf{t} \\
\mathrm{B}\end{array}$} & \multirow{2}{*}{$\begin{array}{c}\text { Sig. } \\
\text { Std. Error }\end{array}$} \\
\hline & & $B$ & Std. Error & & & \\
\hline \multirow[t]{2}{*}{1} & (Constant) & 2.094 & .409 & & 5.118 & .000 \\
\hline & $\begin{array}{l}\text { For employees to be } \\
\text { productive, employers } \\
\text { should provide promotion } \\
\text { opportunities }\end{array}$ & .402 & .098 & .344 & 4.098 & .000 \\
\hline
\end{tabular}

Table 10: Coefficients (Researcher field survey 2014).

\begin{tabular}{|l|c|c|c|c|}
\hline Model & $\mathbf{R}$ & $\mathbf{R}$ Square & Adjusted R Square & Std. Error of the Estimate \\
\hline 1 & $.193(\mathrm{a})$ & .037 & .030 & .947 \\
\hline
\end{tabular}

Table 11: Model Summary (Researcher field survey 2014).

\begin{tabular}{|l|c|c|c|c|c|c|}
\hline Model & & Sum of Squares & df & Mean Square & F & Sig. \\
\hline 1 & Regression & 4.345 & 1 & 4.345 & 4.845 & $.030(a)$ \\
\hline & Residual & 112.096 & 125 & .897 & & \\
\hline & Total & 116.441 & 126 & & & \\
\hline
\end{tabular}

Table 12: Anova (Researcher field survey 2014).

\begin{tabular}{|c|c|c|c|c|c|c|}
\hline \multirow[t]{2}{*}{ Model } & & \multicolumn{2}{|c|}{ Unstandardized } & \multirow{2}{*}{\begin{tabular}{|c|} 
Standardized \\
Beta \\
\end{tabular}} & \multirow{2}{*}{$\begin{array}{l}\mathbf{t} \\
\mathrm{B}\end{array}$} & \multirow{2}{*}{$\begin{array}{c}\text { Sig. } \\
\text { Std. Error }\end{array}$} \\
\hline & & $B$ & Std. Error & & & \\
\hline \multirow[t]{2}{*}{1} & (Constant) & 2.936 & .340 & & 8.639 & .000 \\
\hline & $\begin{array}{l}\text { Getting feedback } \\
\text { from employers gives } \\
\text { employees opportunity to } \\
\text { perform better }\end{array}$ & .203 & .092 & .193 & 2.201 & .030 \\
\hline
\end{tabular}

Table 13: Coefficients (a) (Researcher field survey 2014)

in the table. Based on the analysis above for which all calculated values are above the critical values, the null hypothesis (H0) is therefore, rejected while the alternative hypothesis ( $\mathrm{H} 1)$ is accepted; which states that promotion opportunities will lead to increase in labour productivity (Table 11).

\section{Hypothesis 4}

H04: Giving feedback will not improve competitive advantage.

In the model summary table above, $\mathrm{R}^{2}$ of .037 indicates that $37 \%$ of variation in $\mathrm{Y}$ is explained by the variation in the independent variables. This percentage is good enough in determining the goodness of fit for the model (regression equation). After taking into account the number of predictor variables in the model, adjusted $\mathrm{R}^{2}$ yielded a $30 \%$ variation which is moderately significant in this analysis (Table 12).

a. Predictors: (Constant), getting feedback from employers gives employees opportunity to perform better

b. Dependent Variable: For improved competitive positioning, feedback is necessary

c. Dependent Variable: For improved competitive positioning, regular feedbacks is necessary

The table seeks to explain which of the variables is making a statistically significant unique contribution to the model looking at the sig column in the table. The analysis above indicates that all calculated values are above the critical values, the null hypothesis $(\mathrm{H} 0)$ is therefore, rejected while the alternative hypothesis (H1) is accepted; which states that giving feedback will improve competitive positioning. The ANOVA table shows the assessment of the statistical significance ( $\mathrm{sig}=0.000$ ), in which the F-value is equal to 4.845 , and less than or equal to 0.05 , therefore we reject the null hypothesis (Table 13).

\section{Managerial Implications and Conclusion}

Performance appraisal has become a fundamental tool used for facilitate organizational effectiveness and greater employees' commitment in the workplace. The study pointed that if employees were well rewarded and promoted for job done, it will increase their commitment and loyalty in the organization. In the same vein, if employees were properly motivated with the necessary and adequate 
training needs, innovation would increase rapidly on the job and this will thereby lead to competitive positioning. Most respondents affirmed that promotion increases their satisfaction and level of productivity in the organization. In addition to this, employees agreed that if they got regular feedbacks about their performance on the jobs, it could secure competitive positioning for the organization. As this will help them to identify their strengths and weaknesses which could invariably produce opportunities or threat to the organization they are working with. Theoretically, the goal setting theory supported the findings that individual goals set by employees would motivate them to perform better in the organization this is because the employees keep following those set goals and in situations where it seems the goals cannot be actualized, the goals are either modified or made more realistic. However, individuals' attitude to work is influenced by the expected returns. The employees would respond either positively or negatively in an organization to its goals based on its anticipated satisfaction. All these theories showed a high level of relationship that exists between performance appraisal and productivity in an organization which relates to the perception of employees towards the performance appraisal process and it being a positive one. In today's modern sector, there is a high level of competitive rivalry and rapid increase in technology, organization must learn to integrate its employees to the changes seriously and use the performance appraisal more to motivate and encourage its employees other than just measuring performance, this would give the organization a competitive edge in the industry. Employers' should also invest more in the employees by taking out time to interact with them in order to know the challenges confronting them. Employers should endeavor to practice a consistent good feedback system so as to make the employers have a feeling of involvement in the appraisal system. Finally, the performance appraisal should be structured in a manner that will give room to identify other deficiencies that necessarily would not reflect in the performance evaluation form.

Computers have been playing an increasing role in PA for some time [34]. There are two main aspects to this. The first is in relation to the electronic monitoring of performance, which affords the ability to record a huge amount of data on multiple dimensions of work performance. Not only does it facilitate a more continuous and detailed collection of performance data in some jobs, e.g. call centres, but it has the capacity to do so in a non-obvious, covert manner. The second aspect is in mediating the feedback process, by recording and aggregating performance ratings and written observations and making the information available on-line; many software packages are available for this. The use of IT in these ways undoubtedly helps in making the appraisal process more manageable, especially where multiple rating sources are involved, but it also raises many questions about appraises' reactions and possible effects on PA outcomes. Mostly, the evidence so far is positive [35].

\section{Biography}

SALAU, Odunayo Paul obtained his B.Sc \& M.Sc degrees in Industrial Relations and Human Resource Management. SALAU is a man endowed with passion for teaching and learning. He is with the objective of striving for excellence and precision at all times, in all positions and circumstances, obtaining professional distinction and academic proficiency. Presently, he is a Lecturer and a Doctoral student at Covenant University and his research interest in Industrial Relations and Human Resource Management.

\section{References}

1. Caruth DL, Humphreys JH (2008) Performance Appraisal: Essential
Characteristics for Strategic Control. Measuring Business Excellence 12 24-32.

2. Sole F (2009) 'A Management Model and Factors Driving Performance in Public Organizations'. Measuring Business Excellence 13: 3-11.

3. Moorhead G, Griffin RW (1992) Organizational Behavior (3rd Edition). Boston: Houghton Mifflin Company.

4. Brown M, Benson J (2003) 'Rated to Exhaustion? Reactions to Performance Appraisal Processes'. Industrial Relations Journal 34: 67-81

5. Cook J, Crossman A (2004) 'Satisfaction With Performance Appraisal Systems: A study of Role Perceptions'. Journal of Managerial Psychology 19: 526-541.

6. Doleh AJ, Weir D (2007) Dimensions of performance appraisal systems in Jordanian private and public organizations. International Journal of Human Resource Management 18: 75-84.

7. Armstrong M, Baron A (2005) Managing Performance: Performance Management in Action. London: Chartered Institute of Personnel and Development.

8. Armstrong M (2001) Human Resource Management Practice, (8thed.) London: Kogan Page Publishers.

9. Gupta A, Upadhyay D (2012) Impact of effectiveness of performance management system on employee satisfaction and commitment. International Journal of Management, IT and Engineering 2.

10. Moulder E (2001) Performance Appraisals for local government employees: Programs and Practices. Washington: D.C

11. Mansor NA (2011)'Determinants of performance management system in South East Asia', Interdisciplinary Journal of Contemporary Research in Business 3 43-56.

12. Lee CD (2005) Rethinking the goals of your performance management system. Employment Relations Today 32: 53-60.

13. Erdogan B (2002) 'Antecedents and Consequences of Justice Perceptions in Performance Appraisals'. Human Resource Management Review 12: 555-578.

14. Fletcher C (2001) 'Performance Appraisal and Management: The Developing Research Agenda'. Journal of Occupational and Organizational Psychology 74 473-487.

15. Coens T, Jenkins M (2000) Abolishing Performance Appraisals: Why They Backfire and What to Do Instead. San Francisco: Berrett-Koehler Publishers.

16. Preston BJ, Steel L (2002) Employees customers, and internal marketing strategies in LIS. Library Management 23: 384-393.

17. Prowse P, Prowse J (2009) The Dilemma of Performance Appraisal. Journal of Measuring Business Excellence 13: 69-77

18. Chiang F, Birtch T (2010) Appraising performance across borders: An empirica examination of the purposes and practices of performance appraisal in a multicountry context. Journal of Management Studies 47: 1365-1393.

19. Hartog DD, Boselie P, Paaiwe, J (2004) Performance management: A mode and research agenda. Applied Psychology: An International Review 53: 556560 .

20. Keeping LM, Levy PE (2000) Performance appraisal reactions: measurement modeling, and method bias. Journal of Applied Psychology 85: 708-723.

21. Muchinsky P M (2006) Psychology applied to work (8th ed). Belmont, CA: Thomson Wadsworth.

22. Lawler EE (2003) 'Reward and performance management system effectiveness'. Organizational Dynamics 32: 396-404.

23. Mone EM, London M (2010) Employee Engagement through Effective Performance Management: A Practical Guide for Managers. New York: Routledge.

24. Roberson QM, Stewart MM (2006) 'Understanding the Motivational Effects of Procedural and Informational Justice in Feedback Processes'. British Journal of Psychology 97: 281-298.

25. Schraeder M, Becton J, Portis R (2007) A critical examination of performance appraisals. The Journal for Quality and Participation 21: 20-25.

26. Macey WH, Schneider B, Barbera K.M, Young SA (2009) Employee 
Citation: Paul SO, Olumuyiwa FO, Esther OA (2015) Modelling the Relationship between Performance Appraisal and Organizational Productivity in Nigerian Public Sector. J Glob Econ 3: 129. doi:10.4172/2375-4389.1000129

Page 8 of 8

engagement: tools for analysis, practice, and competitive advantage. Malden WA: Wiley-Blackwell.

27. Brown M, Hyatt D, Benson J (2010) Consequences of the performance appraisal experience: Personnel Review 39: 375-396.

28. Cawley BD, Keeping LM, Levy PE (1998) 'Participation in the performance appraisal process and employee reactions: A meta-analytic review of field investigations'. Journal of Applied Psychology 83: 615-633.

29. DeNisi A, Pritchard R (2006) Performance appraisal, performance management and improving individual performance: A motivational framework. Management and Organization Review 2: 253-277.

30. Pettijohn L, Parker R, Pettijohn C, Kent J (2001) Performance appraisals: usage, criteria, and observations. The Journal of Management Development 20: 754-771
31. Rao TV (2004) Performance Management and Appraisal systems; HR tools for global competitiveness, New Delhi: Response Books (A division of Sage Publications).

32. Selden SC, Ingraham PW, Jacobson W (2001) Human resource practices in state government: Findings from a national survey. Public Administration Review 61: 598-607.

33. Soltani E (2005) Conflict between theory and practice: TQM and performance appraisal. The International Journal of Quality and Reliability Management 22:796-818.

34. Storey J, Sisson K (1993) Managing Human Resources and Industria Relations. Buckingham: The Open University Press.

35. Sudarsan A (2009) Performance appraisal systems: A survey of organizational views. The Icfai University Journal of Organizational Behavior 3: 54-69. 